\title{
Warming temperatures could expose more than 1.3 billion new people to Zika virus risk by 2050
}

\author{
Sadie J. Ryan ${ }^{1,2,3}$ (D) | Colin J. Carlson ${ }^{4}$ (D) | Blanka Tesla ${ }^{5,6}$ | Matthew H. Bonds ${ }^{7}$ | \\ Calistus N. Ngonghala ${ }^{2,8}$ (D) | Erin A. Mordecai ${ }^{9}$ | Leah R. Johnson ${ }^{10,11}$ (D) | \\ Courtney C. Murdock ${ }^{5,6,12,13,14,15,16}$ \\ ${ }^{1}$ Department of Geography, University of Florida, Gainesville, FL, USA \\ ${ }^{2}$ Emerging Pathogens Institute, University of Florida, Gainesville, FL, USA \\ ${ }^{3}$ School of Life Sciences, University of KwaZulu-Natal, Durban, South Africa \\ ${ }^{4}$ Department of Biology, Georgetown University, Washington, DC, USA \\ ${ }^{5}$ Department of Infectious Diseases, College of Veterinary Medicine, University of Georgia, Athens, GA, USA \\ ${ }^{6}$ Center for Tropical and Emerging Global Diseases, University of Georgia, Athens, GA, USA \\ ${ }^{7}$ Department of Global Health and Social Medicine, Harvard Medical School, Boston, MA, USA \\ ${ }^{8}$ Department of Mathematics, University of Florida, Gainesville, FL, USA \\ ${ }^{9}$ Biology Department, Stanford University, Stanford, CA, USA \\ ${ }^{10}$ Department of Statistics, Virginia Polytechnic Institute and State University, Blacksburg, VA, USA \\ ${ }^{11}$ Computational Modeling and Data Analytics, Virginia Polytechnic Institute and State University, Blacksburg, VA, USA \\ ${ }^{12}$ Odum School of Ecology, University of Georgia, Athens, GA, USA \\ ${ }^{13}$ Center for the Ecology of Infectious Diseases, University of Georgia, Athens, GA, USA \\ ${ }^{14}$ Center for Vaccines and Immunology, College of Veterinary Medicine, University of Georgia, Athens, GA, USA \\ ${ }^{15}$ Riverbasin Center, University of Georgia, Athens, GA, USA \\ ${ }^{16}$ Department of Entomology, College of Agriculture and Life Sciences, Cornell University, Ithaca, NY, USA
}

\section{Correspondence}

Sadie J. Ryan, Department of Geography, University of Florida, Gainesville, FL, USA

Email: sjryan@ufl.edu

\section{Funding Information}

S.J.R., L.R.J., and E.A.M. were supported by NSF EEID (DEB-1518681), and E.A.M., C.C.M., B.T., M.H.B., and C.N.N. were supported by the National Science Foundation, Grants for Rapid Response Research (NSF-RAPID 1640780). E.A.M was additionally supported by the NIH (R35GM133439), NSF EEID (DEB-2011147), the Terman Award, the Helman Scholarship, and a Stanford University King Center for Global Development Seed Grant. [Correction added on 9 November 2020, after first online publication: the Funding Information has been updated.]

\begin{abstract}
In the aftermath of the 2015 pandemic of Zika virus (ZIKV), concerns over links between climate change and emerging arboviruses have become more pressing. Given the potential that much of the world might remain at risk from the virus, we used a previously established temperature-dependent transmission model for ZIKV to project climate change impacts on transmission suitability risk by mid-century (a generation into the future). Based on these model predictions, in the worst-case scenario, over 1.3 billion new people could face suitable transmission temperatures for ZIKV by 2050. The next generation will face substantially increased ZIKV transmission temperature suitability in North America and Europe, where naïve populations might be particularly vulnerable. Mitigating climate change even to moderate emissions scenarios could significantly reduce global expansion of climates suitable for ZIKV transmission, potentially protecting around 200 million people. Given these suitability risk
\end{abstract}

Sadie J. Ryan and Colin J. Carlson contributed equally to this study.

This is an open access article under the terms of the Creative Commons Attribution-NonCommercial-NoDerivs License, which permits use and distribution in any medium, provided the original work is properly cited, the use is non-commercial and no modifications or adaptations are made.

(c) 2020 The Authors. Global Change Biology published by John Wiley \& Sons Ltd 
projections, we suggest an increased priority on research establishing the immune history of vulnerable populations, modeling when and where the next ZIKV outbreak might occur, evaluating the efficacy of conventional and novel intervention measures, and increasing surveillance efforts to prevent further expansion of ZIKV.

\section{KEYWORDS}

Aedes aegypti, arboviruses, climate change, disease risk, vector-borne diseases, Zika virus

\section{1 | INTRODUCTION}

In the past two decades, several emerging arboviruses have undergone continental or global range expansions. Often, these viruses only become major research targets after sizable outbreaks in the Western hemisphere, like the 1999-2002 West Nile virus outbreak in the United States and Canada (Sejvar, 2003), the 2013-2015 chikungunya outbreak in the Americas, and, most recently, the 2015-2017 epidemic of Zika virus (ZIKV) in the Americas. Although these outbreaks often take public health communities by surprise (Amraoui \& Failloux, 2016; Chan et al., 2016), their international spread occurred gradually with limited global concern and little action before a major outbreak occurred (Musso et al., 2018). Given the conditions that permit novel emergence and spread are bounded by current climate, it will be important to understand the shifts in climate that will permit future transmission. In the aftermath of the Zika pandemic, developing tools that can successfully anticipate the changing climate conditions that promote these sorts of explosive arbovirus outbreaks is a critical research need (Muñoz et al., 2017; Weaver, 2018).

Zika virus continues to pose a looming threat. Since 2013, the virus spread to at least 49 countries and territories (O'Reilly et al., 2018), resulting in an estimated 150,000-500,000 cases with at least 3,000 cases of microcephaly in Brazil alone (Chan et al., 2016). While other emerging and re-emerging viruses have much higher case-fatality rates (Centers for Disease Control \& Prevention, 2013), such as yellow fever virus or Eastern equine encephalitis virus, the social and human costs of microcephaly are profound (Waldorf et al., 2018). In the aftermath of the epidemic in the Americas (O'Reilly et al., 2018; Siedner et al., 2018), concern remains about potential future outbreaks of the virus and its ongoing relevance as a public health threat. In Latin America and the Caribbean (LAC), high seroprevalence rates would suggest that another major outbreak is unlikely in the short term (Netto et al., 2017; Zambrana et al., 2018). In contrast, ZIKV remains a potential threat at its range margins in the Americas (especially in the southern United States; Carlson et al., 2018; Manore et al., 2017), Africa, and Asia (Bogoch et al., 2016; Dhimal et al., 2018; Siraj \& Perkins, 2017). Although the virus has spread through Africa and Asia for several decades without an outbreak on the scale of the one in the Americas, the seroprevalence of Zika in its native range is poorly characterized. Furthermore, the evolution of novel ZIKV strains may make the threat newly relevant in Africa and Asia (Zhu et al., 2016): local transmission of ZIKV in Angola in 2017 underscores the potential for this problem to occur again (Kraemer et al., 2017).

The relationship between climate change and ZIKV adds an additional layer of complexity. The contribution of climate change to the severity of the 2015 outbreak is difficult to ascertain definitively, and some have suggested links between Zika transmission and El Niño (Caminade et al., 2017). Previous models have suggested that Aedes-borne virus transmission should expand significantly in a changing climate, especially those transmitted by Aedes aegypti (Ryan et al., 2019). Limited modeling work done during the 2016 outbreak suggested that Zika transmission might be constrained to slightly warmer, less seasonally variable parts of the world than dengue (Carlson et al., 2016); and recent work by Tesla et al. (2018) combining experimental and modeling approaches has suggested that the minimum temperature for ZIKV transmission by A. aegypti is roughly $5^{\circ} \mathrm{C}$ higher than that of dengue virus. Thus, while the current range of Zika transmission is confined to the tropics, climate change could increase the number of people exposed for the first time to temperatures suitable for Zika transmission.

Here, we provide the first systematic assessment of where future temperatures are expected to become suitable for transmission, and could most substantially increase the distribution of ZIKV and its risk to human populations. To achieve this, we follow a similar approach described in our previous studies that have used a temperaturedependent transmission model to assess environmental suitability for dengue transmission (Ryan et al., 2019). In this study, we project the Zika-specific model for A. aegypti transmission (Tesla et al., 2018) onto current temperatures and evaluate the population at risk (PAR) based on human population density data from 2015, during the Zika pandemic. We then project the temperature-dependent Zika model forward with climate change to the year 2050 (approximately one human generation into the future) and evaluate where human populations might be expected to face their first exposure to temperatures suitable for ZIKV transmission.

\section{MATERIALS AND METHODS}

In this study, we use an established approach that applies thermal transmission curves to predict suitable areas for arbovirus transmission. Our approach differs from our previous work examining climate change impacts on arboviral risk (Ryan et al., 2019) in two main ways: the present model is specific to Zika virus instead of dengue, 
and our updated approach pairs socioeconomic scenarios with climate pathways.

\subsection{Mechanistic model of temperature suitability for ZIKV transmission}

We used a recently published experimentally derived mechanistic model of ZIKV transmission by A. aegypti to map temperature-driven transmission risk (Tesla et al., 2018). In brief, the approach is to use a Bayesian framework to fit thermal responses for mosquito and virus traits that drive transmission that were empirically estimated in laboratory experiments, and then combine them to obtain the posterior distribution of $R O$ as a function of temperature. The full methods are described in detail in Johnson et al. (2015) and several of the particular traits and fits for A. aegypti are originally presented in Mordecai et al. (2017). The more recent Tesla et al.'s (2018) description of thermal responses included data and fitted thermal performance curves for daily adult mosquito mortality as well as two ZIKV-specific traits: vector competence and the extrinsic incubation rate. The posterior samples for $R O$ as a function of temperature (rescaled to range from zero to one, given that the absolute magnitude of $R O$ in any given setting varies) were generated, and the probability that $R O>0$ at each temperature was obtained, a cutoff inclusive of any transmission risk (not just sustained outbreaks, where $R 0>1$ ). We used the thermal boundaries for which ZIKV RO $>0$ with a posterior probability $>0.975$ to define the limits on suitability for transmission for monthly temperatures, then calculated climate model data layers as described below. This high probability allows us to define a temperature range for potential transmission that is conservative. The final interval of "suitable transmission temperatures" was given as $23.9-34.0^{\circ} \mathrm{C}$.

\section{2 | Climate and population data}

To examine the impact of climate change on transmission risk, we follow the approach of Ryan et al. (2019). Briefly, we obtained 5 -min resolution current mean monthly temperature data from the WorldClim dataset (www.worldclim.org; Hijmans et al., 2005). We then selected four general circulation models (GCMs) and two representative concentration pathways (RCPs $4.5,8.5$ ) to account for different global responses to mitigate climate change. The GCMs are the Beijing Climate Center Climate System Model (BCC-CSM1.1); the Hadley GCM (HadGEM2-AO and HadGEM2-ES); and the National Center for Atmospheric Research's Community Climate System Model (CCSM4). Future scenario climate model output data were acquired from the research program on Climate Change, Agriculture, and Food Security (CCAFS) web portal (http://ccafs-climate.org/ data_spatial_downscaling/), part of the Consultative Group for International Agricultural Research (CGIAR). We used model outputs created using the delta downscaling method, from the IPCC AR5. For visualizations, we used the HadGEM2-ES model, the most commonly used GCM. The mechanistic transmission model was then projected onto the climate data using the "raster" package in R 3.1.1 ("raster"; Hijmans \& van Etten, 2012).

To quantify the PAR, we diverged from the previous approach, and aimed to not just capture projected population growth, but to incorporate influences of predicted economic and social changes during the next half century. Therefore, we updated the methods in Ryan et al. (2019) to incorporate population projection products that contain the Shared Socioeconomic Pathways (SSPs; Jones \& O'Neill, 2016). The SSPs are five alternative population trajectory outcomes based on development, economic, education, and urbanization trends, specifically tailored to responses to climate change and/ or mitigation strategies. The different SSPs (1-5) describe trajectories in which components such as fertility and urban growth are impacted by differences in regional and national equality, conflict, efforts for sustainability, or driven by fossil fuels. Different combinations of SSPs and RCPs can be paired based on plausibility, but this introduces factorial combinations and makes coherent projections about future disease risk more complex, so we reserve exploration of this axis of demographic complexity for future studies. For this study, we selected the SSP2 scenario-a middle of the road scenario-to reflect expected growth and population geography shifts due to processes such as migration and urbanization. We acknowledge that SSP2 and RCP 8.5 are an unlikely combined future scenario (Jones \& O'Neill, 2017; Riahi et al., 2017), but present this as the extreme of our projected continuum. The population product we use here is projected from a baseline population, the Gridded Population of the World (GPW; Center for International Earth Science Information Network (CIESIN), Columbia University, 2016), including the Global Rural-Urban Mapping Project (GRUMP; Center for International Earth Science Information Network (CIESIN)/Columbia University International Food Policy Research Institute - IFPRI, 2011). We therefore chose a baseline population for 2015 from GPW products, to reflect conditions during the recent Zika outbreak, and selected the SSP2 2050 population projection product (Jones \& O'Neill, 2017), available from (http://sedac.ciesin.colum bia.edu/data/set/popdynamics-pop-projection-ssp-2010-2100/data-download). We aggregated all geographic layers in our analyses to a $0.25^{\circ}$ grid cell to be consistent.

\subsection{Current and future transmission risk}

To examine the impact of climate change on transmission risk, we follow the approach of Ryan et al. (2019). This previous work used existing Aedes transmission models (which are mostly appropriate for dengue; Mordecai et al., 2017) to project climate change impacts, by mapping areas where mean temperatures fall within the $97.5 \%$ posterior probability, or $95 \%$ credibility interval for suitability predicted by the Bayesian model. These maps can be projected onto different climate futures (different GCMs and RCPs), and populations at risk can be compared between current and future maps. Following this protocol, we overlay suitability maps and population grids for 2015 and 2050 (with different climate pathways for the latter) and 
calculate global PAR. For each analysis, we also stratify these estimates with a regional breakdown using the definitions of the Global Burden of Disease (GBD) study regions to align with policy and planning goals (Moran et al., 2012).

\section{3 | RESULTS}

At present, most of the predicted transmission risk for ZIKV occurs in the tropics (Figure 1). Using the Tesla et al.'s (2018) thermal boundary projection map, we find a "PAR" for 2015 of $~ 5$ billion (here referring to any population inside pixels evaluated as thermally suitable for at least 1 month of the year; Table 1). It is important to note that this thermal boundary does not distinguish whether or not A. aegypti or ZIKV are currently present in a region. Outside LAC, we find a PAR of 4.69 billion (mostly in South and East Asia). In contrast to the large proportion of the global population experiencing any temperature suitability for ZIKV, we find a total population-at-risk of 858 million (the vast majority, 767 million, outside LAC) in areas with year-round temperature suitability for transmission (pixels evaluated as thermally suitable for 12 months; Table 2), highlighting the locations with the most suitable climates where ZIKV importation could lead to sustained outbreaks.

We predict that unmitigated climate change could shift as many as 1.33 billion new people (1.17 billion outside LAC) into areas with future temperatures suitable for ZIKV transmission under the worstcase scenario (RCP 8.5; Table 3). Five regions with populations of 100 million or more people are projected to experience climate suitability for Zika transmission: East Africa, High-income North America, East Asia, Western Europe, and North Africa and the Middle East (with regions designated by the GBD study). A total of 737 million people worldwide (635.8 million outside LAC) could face their first exposure to year-round climate suitability for Zika transmission, mostly in South and East Asia and sub-Saharan Africa.

Net changes in risk are dramatic, largely because there are very few areas where climate warming will drive future temperatures to become unsuitable (too hot) for at least one month of the year, but many areas where the climate will become newly suitable (Figure 2). For any transmission risk suitability (Table 1), we find a net increase of 2.71 billion ( 2.52 billion outside LAC) people at risk in the worstcase scenario (RCP 8.5). Even in the more moderate scenario for
TABLE 1 Current and projected net changes in population at risk for any transmission (one or more months). All values are given in millions; future projections are averaged across general circulation models, broken down by year (2050) and representative concentration pathway (RCP: $4.5,8.5$ ), and are given as net change from a baseline of 2015 population at risk. Totals are given globally, or across all regions except for Latin America and the Caribbean (LAC)

\begin{tabular}{|c|c|c|c|}
\hline \multirow[b]{2}{*}{ Region } & \multirow[b]{2}{*}{2015} & \multicolumn{2}{|l|}{2050} \\
\hline & & RCP 4.5 & RCP 8.5 \\
\hline Asia (Central) & 56.5 & 20.3 & 24.8 \\
\hline Asia (East) & $1,113.5$ & 50.3 & 83.8 \\
\hline $\begin{array}{l}\text { Asia (High-Income } \\
\text { Pacific) }\end{array}$ & 138.1 & -5.8 & -4.2 \\
\hline Asia (South) & $1,621.9$ & 639.2 & 644.7 \\
\hline Asia (Southeast) & 520.7 & 133.7 & 142.5 \\
\hline Australasia & 5.3 & 11.4 & 14.5 \\
\hline Caribbean & 33.8 & 2.2 & 2.7 \\
\hline Europe (Central) & 0.6 & 52.2 & 67.7 \\
\hline Europe (Eastern) & 5.0 & 69.5 & 91.0 \\
\hline Europe (Western) & 42.9 & 106.9 & 131.2 \\
\hline Latin America (Andean) & 17.3 & 15.1 & 16.0 \\
\hline Latin America (Central) & 110.8 & 66.1 & 76.0 \\
\hline $\begin{array}{l}\text { Latin America } \\
\text { (Southern) }\end{array}$ & 15.1 & 30.8 & 31.9 \\
\hline Latin America (Tropical) & 119.7 & 56.8 & 67.0 \\
\hline $\begin{array}{l}\text { North Africa and Middle } \\
\text { East }\end{array}$ & 359.6 & 262.9 & 275.3 \\
\hline $\begin{array}{l}\text { North America (High } \\
\text { Income) }\end{array}$ & 163.9 & 195.9 & 213.8 \\
\hline Oceania & 4.2 & 4.0 & 4.2 \\
\hline $\begin{array}{l}\text { Sub-Saharan Africa } \\
\text { (Central) }\end{array}$ & 86.1 & 100.2 & 106.3 \\
\hline Sub-Saharan Africa (East) & 179.8 & 315.3 & 344.9 \\
\hline $\begin{array}{l}\text { Sub-Saharan Africa } \\
\text { (Southern) }\end{array}$ & 14.3 & 29.4 & 37.3 \\
\hline $\begin{array}{l}\text { Sub-Saharan Africa } \\
\text { (West) }\end{array}$ & 373.8 & 340.4 & 341.0 \\
\hline Total & $4,928.7$ & $2,496.8$ & $2,712.5$ \\
\hline Total outside LAC & $4,686.0$ & $2,325.8$ & $2,518.9$ \\
\hline
\end{tabular}

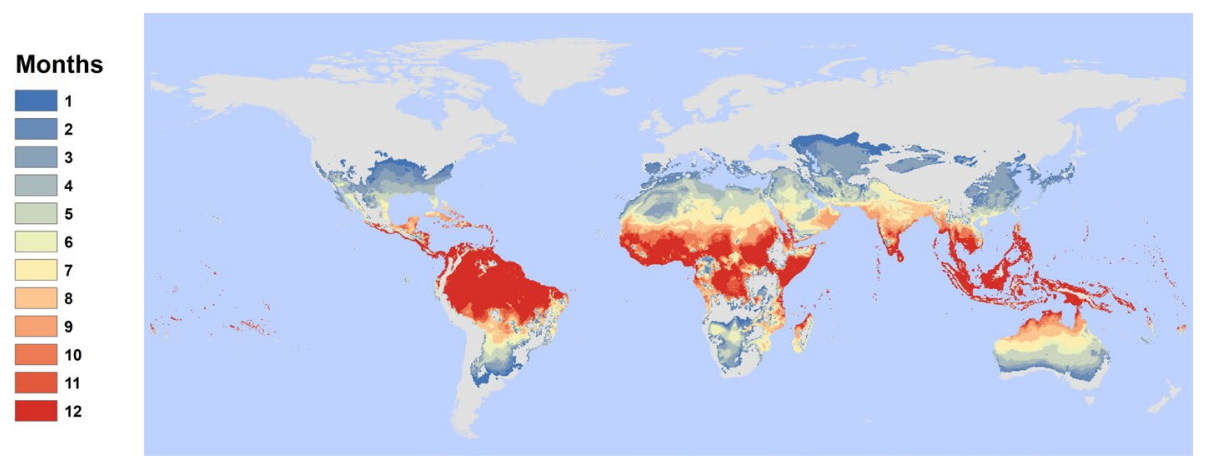

FIGURE 1 Current distribution of temperature suitability for Zika transmission, by month. Results show the number of suitable months per year based on a $97.5 \%$ posterior probability for $R O(T)>0$ based on the Tesla et al. (2018) model of Zika transmission, as a function of mean monthly temperature in each pixel 
TABLE 2 Current and projected net changes for population at risk from year-round transmission risk (12 months). All values are given in millions; future projections are averaged across general circulation models, broken down by year (2050) and representative concentration pathway (RCP: 4.5, 8.5), and are given as net change from current population at risk. Totals are given globally, or across all regions except for Latin America and the Caribbean (LAC)

\begin{tabular}{|c|c|c|c|}
\hline \multirow[b]{2}{*}{ Region } & \multirow{2}{*}{$\begin{array}{l}2015 \\
\text { baseline }\end{array}$} & \multicolumn{2}{|l|}{2050} \\
\hline & & $\mathrm{RCP} 4.5$ & RCP 8.5 \\
\hline Asia (Central) & 0 & 0 & 0 \\
\hline Asia (East) & 0 & 0 & 0.005 \\
\hline Asia (High-Income Pacific) & 2.7 & 1.5 & 1.4 \\
\hline Asia (South) & 104.5 & 111.4 & 107.6 \\
\hline Asia (Southeast) & 356.7 & 164.0 & 179.0 \\
\hline Australasia & 0.1 & 0.1 & 0.1 \\
\hline Caribbean & 7.5 & 15.2 & 19.1 \\
\hline Europe (Central) & 0 & 0 & 0 \\
\hline Europe (Eastern) & 0 & 0 & 0 \\
\hline Europe (Western) & 0 & 0 & 0 \\
\hline Latin America (Andean) & 5.2 & 8.8 & 10.2 \\
\hline Latin America (Central) & 43.7 & 44.3 & 55.0 \\
\hline Latin America (Southern) & 0 & 0 & 0 \\
\hline Latin America (Tropical) & 35.0 & 16.5 & 23.2 \\
\hline $\begin{array}{l}\text { North Africa and Middle } \\
\text { East }\end{array}$ & 5.0 & -1.3 & -0.01 \\
\hline $\begin{array}{l}\text { North America (High } \\
\text { Income) }\end{array}$ & 0 & 0.001 & 0.01 \\
\hline Oceania & 2.5 & 3.3 & 3.8 \\
\hline $\begin{array}{l}\text { Sub-Saharan Africa } \\
\text { (Central) }\end{array}$ & 28.0 & 92.0 & 106.6 \\
\hline Sub-Saharan Africa (East) & 39.7 & 106.8 & 148.3 \\
\hline $\begin{array}{l}\text { Sub-Saharan Africa } \\
\text { (Southern) }\end{array}$ & 0 & 0 & 0 \\
\hline Sub-Saharan Africa (West) & 227.4 & 281.8 & 261.5 \\
\hline Total & 857.9 & 844.3 & 915.9 \\
\hline Total outside LAC & 766.5 & 759.5 & 808.3 \\
\hline
\end{tabular}

climate change mitigation (RCP 4.5), we project a net increase of 2.50 billion people at risk (2.33 billion outside LAC; Table 1). For people living in areas that experience year-round risk (Table 2), we project for the moderate- and worst-case scenarios a minimum increase of 844.3 million (759.5 million outside LAC) and 915.9 million (808.3 million outside LAC), respectively. Therefore, the majority of net changes in people at risk for ZIKV-suitable climates occurs even under the partial mitigation (RCP 4.5) scenario.

In the moderate-case scenario (RCP 4.5), the region experiencing the largest increase in first exposures to any (one or more months) transmission suitability is high-income North America (169.5 million), while under the worst-case scenario (RCP 8.5), the top region is Eastern sub-Saharan Africa (191.1 million); these regional increases are shown in Figure 3.
TABLE 3 Top 10 regional increases. Regions, as defined by the Global Burden of Disease study (Figure S1), are ranked based on millions of people exposed for the first time to any (1 or more months) transmission risk, or to year round (12 months) transmission risk; parentheticals give the net change (first exposures minus populations escaping transmission risk). All values are given for the worst-case scenario (RCP 8.5). Totals are given globally, or across all regions except for Latin America and the Caribbean (LAC)

\begin{tabular}{|c|c|c|c|}
\hline \multicolumn{2}{|c|}{ Any transmission risk } & \multicolumn{2}{|c|}{ Year-round transmission risk } \\
\hline $\begin{array}{l}\text { 1. Sub-Saharan } \\
\text { Africa (East) }\end{array}$ & $191.1(344.9)$ & $\begin{array}{l}\text { 1. Sub-Saharan } \\
\text { Africa (West) }\end{array}$ & $135.1(261.5)$ \\
\hline $\begin{array}{l}\text { 2. North } \\
\text { America (High } \\
\text { Income) }\end{array}$ & $187.4(213.8)$ & $\begin{array}{l}\text { 2. Sub-Saharan } \\
\text { Africa (East) }\end{array}$ & $138.6(148.3)$ \\
\hline 3. Asia (East) & $172.1(83.8)$ & 3. Asia (South) & $127.9(107.6)$ \\
\hline $\begin{array}{l}\text { 4. Europe } \\
\text { (Western) }\end{array}$ & $123.2(131.3)$ & $\begin{array}{l}\text { 4. Asia } \\
\text { (Southeast) }\end{array}$ & 108.5 (179.0) \\
\hline $\begin{array}{l}\text { 5. North Africa } \\
\text { and the Middle } \\
\text { East }\end{array}$ & $107.0(275.3)$ & $\begin{array}{l}\text { 5. Sub-Saharan } \\
\text { Africa (Central) }\end{array}$ & $88.8(106.6)$ \\
\hline $\begin{array}{l}\text { 6. Europe } \\
\text { (Eastern) }\end{array}$ & $91.8(91.0)$ & $\begin{array}{l}\text { 6. Latin America } \\
\text { (Central) }\end{array}$ & $44.3(54.9)$ \\
\hline $\begin{array}{l}\text { 7. Europe } \\
\text { (Central) }\end{array}$ & $67.7(67.7)$ & $\begin{array}{l}\text { 7. Latin America } \\
\text { (Tropical) }\end{array}$ & $28.2(23.2)$ \\
\hline $\begin{array}{l}\text { 8. Latin America } \\
\text { (Tropical) }\end{array}$ & $60.1(66.9)$ & 8. Caribbean & $18.6(19.1)$ \\
\hline $\begin{array}{l}\text { 9. Latin America } \\
\text { (Central) }\end{array}$ & $51.5(76.0)$ & $\begin{array}{l}\text { 9. Latin America } \\
\text { (Andean) }\end{array}$ & $10.0(10.2)$ \\
\hline $\begin{array}{l}\text { 10. Sub-Saharan } \\
\text { Africa (Central) }\end{array}$ & $50.8(106.3)$ & $\begin{array}{l}\text { 10. North Africa } \\
\text { and the Middle } \\
\text { East }\end{array}$ & $4.6(-0.08)$ \\
\hline $\begin{array}{l}\text { Total (across all } \\
21 \text { regions) }\end{array}$ & $\begin{array}{l}1,326.5 \\
(2,712.5)\end{array}$ & $\begin{array}{l}\text { Total (across all } \\
21 \text { regions) }\end{array}$ & $736.9(915.9)$ \\
\hline $\begin{array}{l}\text { Total (outside } \\
\text { LAC) }\end{array}$ & $\begin{array}{l}1,168.5 \\
(2,518.9)\end{array}$ & $\begin{array}{l}\text { Total (outside } \\
\text { LAC) }\end{array}$ & $635.6(808.3)$ \\
\hline
\end{tabular}

\section{4 | DISCUSSION}

We present an upper bound on potential future expansion of ZIKV transmission risk based on thermal suitability in a changing climate. When compared to mapped projections for dengue transmission suitability in A. aegypti (Ryan et al., 2019), we see a more constrained geographic range, as the lower temperature limit modeled for ZIKV transmission is higher, precluding cooler regions. This difference in predicted spatial suitability corroborates findings from distribution modeling approaches to human case data for dengue and ZIKV (Carlson et al., 2016), underscoring the importance of understanding transmission biology of specific vector-pathogen pairings. Our mechanistic, trait-based modeling approach has successfully characterized the distribution of several vector-borne diseases, including dengue (Mordecai et al., 2017), malaria (Mordecai et al., 2013), and Ross River fever (Shocket et al., 2018).

Our results here indicate that warming temperatures will increase thermal suitability for ZIKV transmission in a significant portion of 

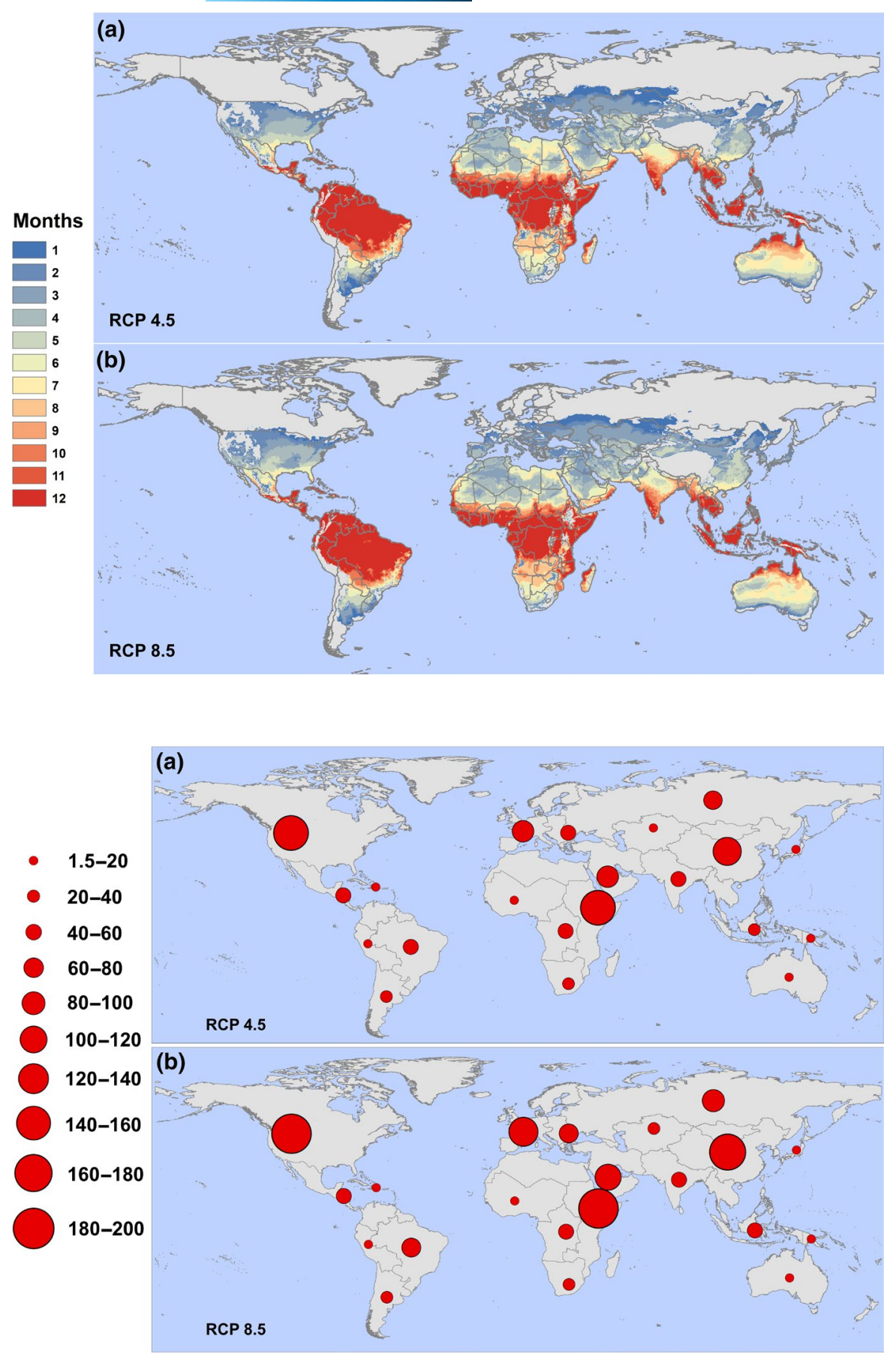

FIGURE 2 A moderate-case and worst-case scenario for 2050. The figure shows our model projecting Zika transmission risk for (a) RCP 4.5 and (b) RCP 8.5 (HadGEM2-ES). Results show the number of suitable months per year based on a $97.5 \%$ posterior probability for $R O(T)>0$ based on the Tesla et al. (2018) model of Zika transmission, as a function of mean monthly temperature in each pixel. Country outlines are shown from the global administrative boundaries dataset (gadm.org), to facilitate visualizing differences between the scenarios

FIGURE 3 Regional increases in populations at risk for any transmission (one or more months). Regions are defined according to the Global Burden of Disease regions (detailed in Figure S1), and proportional red circles illustrate the regional populations (in millions) at risk under (a) RCP 4.5 and (b) RCP 8.5 the world, with over 1.3 billion people likely to be exposed for the first time to temperature conditions suitable for Zika transmission by the mid-century in the worst-case scenario. In combination with population change in at-risk areas, this produces an increase in the PAR on the order of 2.7 billion people. Whether this risk leads to actual re-emergence events depends on several limiting factors, most of all the presence or absence of competent mosquito vectors. The Zika transmission model presented here already designates some areas as suitable that are outside the range of $A$. aegypti, the main vector, or A. albopictus, another competent vector of concern. However, both A. aegypti and A. albopictus are projected to expand their range to higher latitudes and elevations, with some indication this has already happened (Armstrong et al., 2017; Hernández-Amparan et al., 2017). Other studies have also highlighted the potential for ZIKV to be transmitted by other mosquitoes that are widespread in the rest of the predicted range (Evans et al., 2017; Gendernalik et al., 2017; Weger-Lucarelli et al., 2016); each new mosquito vector species and its relative contribution to potential transmission would introduce subtle differences in the realized climate suitability and effects of climate change on ZIKV transmission (Mordecai et al., 2017; Ryan et al., 2019). Even where conditions are suitable and mosquito vectors are present, repeated importation may not lead to establishment (Fox et al., 2018; Grubaugh et al., 2017) due to a combination of stochasticity and confounding and interconnected 
socioenvironmental risk factors (e.g., housing construction, water storage, mosquito control, and surveillance efforts; Ali et al., 2017; Christofferson, 2018).

As the risk areas for ZIKV expand, prioritizing regions for intervention become more difficult. Several major research advances can improve predictions. Testing the competence of Aedes mosquitoes and others to transmit the virus and identifying regional differences in competence are key steps (Boyer et al., 2018; Calvez, O'Connor, et al., 2018; Calvez, Mousson, et al., 2018; Duchemin et al., 2017; Gendernalik et al., 2017; Kauffman \& Kramer, 2017; Weger-Lucarelli et al., 2016). The impacts of the immune history and genetic risk factors of human populations are an additional critical component of the system (Rodriguez-Barraquer et al., 2019). Seroprevalence studies indicate that another catastrophic Zika epidemic is unlikely in LAC in the near term (Netto et al., 2017; Zambrana et al., 2018), but much less is known about ZIKV susceptibility in African, Asian, and Pacific Islander populations. Similarly, microcephaly rates in response to ZIKV infection varied even within the Americas, with the highest rates in Brazil (Johansson et al., 2016) and lower rates in the Caribbean (Francis et al., 2018), suggesting significant variation exists across human populations in the severity of symptoms associated with ZIKV infection. Given the potential for explosive outbreaks in naïve populations (as happened in the Americas), this is a top priority for predicting the potential for future outbreaks. The relevance of ZIKV in the coming decades will be determined by the overall risk of microcephaly, Zika congenital syndrome more broadly, and Guillain-Barre syndrome-the most severe manifestations of ZIKV infection-which remain poorly understood.

Other features of the abiotic environment, like precipitation, relative humidity, or solar radiation, also constrain the distribution of vectors and their pathogens, as do biotic interactions and human-modified features of the landscape. Some of these factors impact transmission in ways that can be surprising. For example, typically it is assumed that increased precipitation should increase arboviral transmission, due to increasing potential larval habitat. However, during the 2015-2017 ZIKV outbreak, there was an inverse relationship with precipitation: drought led to greater transmission because increases in household water storage were associated with increased Zika cases (Ali et al., 2017; BurgerCalderon et al., 2018; a pattern also observed in previous arbovirus outbreaks, Shragai et al., 2017). Importantly, as mosquitoes are ectothermic, and the effects of precipitation on transmission are not straightforward, using thermal suitability allows us to set range boundaries on future risk, both geographically and seasonally. Moreover, in addition to average temperature suitability, temperature variation can play an important and nonlinear role in transmission, at the level of the vector (Murdock et al., 2012), potentially increasing environmental suitability for transmission at low mean temperatures. In addition to this, warming in areas with higher mean temperatures is predicted to reduce suitability, as conditions pass beyond optimal transmission suitability temperatures. This can lead to reductions in predicted risk, as seen in the high-income Pacific Asia region (Table 1); this echoes findings for malaria suitability in
Africa, seen in Ryan et al. (2015, 2020), wherein Western Africa becomes too hot for malaria suitability, and risk appears to decline rapidly under climate change scenarios. Given the high upper thermal bounds of transmission suitability of ZIKV, other direct or indirect impacts of heat on human health are likely to arise, meaning the predicted declines at high temperatures are not necessarily an optimistic picture. Our temperature-based approach isolates one of the strongest environmental filters, and avoids confounding issues of the relationship between precipitation and arboviruses that occurs in the urban environment, where human behavior and water practices may drive dynamics; put simply, for urban arboviral transmission, where people are, so is water. Hopefully, the future risk we project in this study is likely to be substantially constrained by limiting protective factors from vector-borne disease infection, including socioeconomic, immunological, intervention, and environmental factors, including the built environment itself.

The ZIKV outbreak originating in Brazil in 2015 quickly became a historically significant global health emergency, highlighting the growing threat of emerging diseases in a changing world (Shragai et al., 2017). Even in the moderate-case mitigation scenario (RCP 4.5) considered here, climate change will substantially increase climate suitability for Zika outbreaks in tropical and temperate zones around the world. With the economic and social costs of the 2015-2017 pandemic still accumulating, our results suggest another case in which climate change mitigation is unequivocally necessary for the sake of global health security.

\section{ACKNOWLEDGEMENTS}

Thanks to Fausto Bustos for critical comments on Zika immunology. We would also like to thank Dr. Melinda Brindley and Leah Demakovsky in the design and execution of the study that generated the Zika virus data that informed our temperature-dependent $R O$ model.

\section{CONFLICT OF INTEREST}

The authors declare no conflict of interest.

\section{AUTHOR CONTRIBUTION}

S.J.R., C.J.C., E.A.M., C.C.M., L.R.J., and B.T. designed the modeling and analysis frameworks. C.J.C. and S.J.R. performed the analyses and wrote the first draft. All authors contributed to the writing and design of the paper and approved the final submission.

\section{DATA AVAILABILITY STATEMENT}

The data that support the findings of this study-model outputs of Zika suitability-are openly available at the Harvard Dataverse at https://doi.org/10.7910/DVN/TK041G, https://doi.org/10.7910/ DVN/GSFYAW, and https://doi.org/10.7910/DVN/IEOD14.

\section{ORCID}

Sadie J. Ryan (iD https://orcid.org/0000-0002-4308-6321

Colin J. Carlson (iD https://orcid.org/0000-0001-6960-8434

Calistus N. Ngonghala iD https://orcid.org/0000-0002-8441-9495

Leah R. Johnson (iD https://orcid.org/0000-0002-9922-579X 


\section{REFERENCES}

Ali, S., Gugliemini, O., Harber, S., Harrison, A., Houle, L., Ivory, J., Kersten, S., Khan, R., Kim, J., LeBoa, C., Nez-Whitfield, E., O'Marr, J., Rothenberg, E., Segnitz, R. M., Sila, S., Verwillow, A., Vogt, M., Yang, A., \& Mordecai, E. A. (2017). Environmental and social change drive the explosive emergence of Zika virus in the Americas. PLoS Neglected Tropical Diseases, 11(2), e0005135. https://doi.org/10.1371/journ al.pntd.0005135

Amraoui, F., \& Failloux, A.-B. (2016). Chikungunya: An unexpected emergence in Europe. Current Opinion in Virology, 21, 146-150. https://doi. org/10.1016/j.coviro.2016.09.014

Armstrong, P. M., Andreadis, T. G., Shepard, J. J., \& Thomas, M. C. (2017). Northern range expansion of the Asian tiger mosquito (Aedes albopictus): Analysis of mosquito data from Connecticut, USA. PLoS Neglected Tropical Diseases, 11(5), e0005623. https://doi. org/10.1371/journal.pntd.0005623

Bogoch, I. I., Brady, O. J., Kraemer, M. U. G., German, M., Creatore, M. I., Brent, S., Watts, A. G., Hay, S. I., Kulkarni, M. A., Brownstein, J. S., \& Khan, K. (2016). Potential for Zika virus introduction and transmission in resource-limited countries in Africa and the Asia-Pacific region: A modelling study. The Lancet Infectious Diseases, 16(11), 1237-1245. https://doi.org/10.1016/S1473-3099(16)30270-5

Boyer, S., Calvez, E., Chouin-Carneiro, T., Diallo, D., \& Failloux, A.-B. (2018). An overview of mosquito vectors of Zika virus. Microbes and Infection, 20(11-12), 646-660. https://doi.org/10.1016/j. micinf.2018.01.006

Burger-Calderon, R., Gonzalez, K., Ojeda, S., Zambrana, J. V., Sanchez, N., Cerpas Cruz, C., Suazo Laguna, H., Bustos, F., Plazaola, M., Lopez Mercado, B., Elizondo, D., Arguello, S., Carey Monterrey, J., Nuñez, A., Coloma, J., Waggoner, J. J., Gordon, A., Kuan, G., Balmaseda, A., \& Harris, E. (2018). Zika virus infection in Nicaraguan households. PLoS Neglected Tropical Diseases, 12(5), e0006518. https://doi. org/10.1371/journal.pntd.0006518

Calvez, E., Mousson, L., Vazeille, M., O'Connor, O., Cao-Lormeau, V.-M., Mathieu-Daudé, F., Pocquet, N., Failloux, A.-B., \& Dupont-Rouzeyrol, M. (2018). Zika virus outbreak in the Pacific: Vector competence of regional vectors. PLoS Neglected Tropical Diseases, 12(7), e0006637. https://doi.org/10.1371/journal.pntd.0006637

Calvez, E., O'Connor, O., Pol, M., Rousset, D., Faye, O., Richard, V., Tarantola, A., \& Dupont-Rouzeyrol, M. (2018). Differential transmission of Asian and African Zika virus lineages by Aedes aegypti from New Caledonia. Emerging Microbes \& Infections, 7(1), 159.

Caminade, C., Turner, J., Metelmann, S., Hesson, J. C., Blagrove, M. S., Solomon, T., Morse, A. P., \& Baylis, M. (2017). Global risk model for vector-borne transmission of Zika virus reveals the role of El Niño 2015. Proceedings of the National Academy of Sciences of the United States of America, 114(1), 119-124. https://doi.org/10.1073/ pnas.1614303114

Carlson, C. J., Dougherty, E., Boots, M., Getz, W., \& Ryan, S. (2018). Consensus and conflict among ecological forecasts of Zika virus outbreaks in the United States. Scientific Reports, 8(1), 4921. https://doi. org/10.1038/s41598-018-22989-0

Carlson, C. J., Dougherty, E. R., \& Getz, W. (2016). An ecological assessment of the pandemic threat of Zika virus. PLoS Neglected Tropical Diseases, 10(8), e0004968. https://doi.org/10.1371/journ al.pntd.0004968

Center for International Earth Science Information Network (CIESIN), Columbia University. (2016). Gridded Population of the World, Version 4 (GPWv4). US NASA Socioeconomic Data and Applications Center (SEDAC). Retrieved from http://sedac.ciesin.columbia.edu/data/ set/gpw-v4-population-count-adjusted-to-2015-unwpp-countrytotals

Center for International Earth Science Information Network (CIESIN)/ Columbia University, International Food Policy Research Institute - IFPRI. (2011). Global Rural-Urban Mapping Project, Version 1
(GRUMPv1): Urban Extents Grid. Retrieved from http://sedac.ciesin. columbia.edu/data/set/grump-v1-urban-extents

Centers for Disease Control and Prevention. (2013). West Nile virus and other arboviral diseases-United States, 2012. Morbidity and Mortality Weekly Report, 62(25), 513.

Chan, J. F., Choi, G. K., Yip, C. C., Cheng, V. C., \& Yuen, K.-Y. (2016). Zika fever and congenital Zika syndrome: An unexpected emerging arboviral disease. Journal of Infection, 72(5), 507-524. https://doi. org/10.1016/j.jinf.2016.02.011

Christofferson, R. (2018). Investigating the probability of establishment of Zika virus and detection through mosquito surveillance under different temperature conditions. BioRxiv, 406116.

Dhimal, M., Dahal, S., Dhimal, M. L., Mishra, S. R., Karki, K. B., Aryal, K. K., Haque, U., Kabir, M. I., Guin, P., Butt, A. M., Harapan, H., Liu, Q.Y., Chu, C., Montag, D., Groneberg, D. A., Pandey, B. D., Kuch, U., \& Müller, R. (2018). Threats of Zika virus transmission for Asia and its Hindu-Kush Himalayan region. Infectious Diseases of Poverty, 7(1), 40. https://doi.org/10.1186/s40249-018-0426-3

Duchemin, J.-B., Mee, P. T., Lynch, S. E., Vedururu, R., Trinidad, L., \& Paradkar, P. (2017). Zika vector transmission risk in temperate Australia: A vector competence study. Virology Journal, 14(1), 108. https://doi.org/10.1186/s12985-017-0772-y

Evans, M. V., Dallas, T. A., Han, B. A., Murdock, C. C., \& Drake, J. M. (2017). Data-driven identification of potential Zika virus vectors. eLife, 6, e22053. https://doi.org/10.7554/eLife.22053

Fox, S. J., Bellan, S. E., Perkins, T. A., Johansson, M. A., \& Meyers, L. A. (2018). Downgrading disease transmission risk estimates using terminal importations. BioRxiv, 265942.

Francis, L., Hunte, S.-A., Valadere, A. M., Polson-Edwards, K., AsinOostburg, V., \& Hospedales, C. J. (2018). Zika virus outbreak in 19 English-and Dutch-speaking Caribbean countries and territories, 2015-2016. International Journal of Infectious Diseases, 73, 183. https://doi.org/10.1016/j.ijid.2018.04.3828

Gendernalik, A., Weger-Lucarelli, J., Garcia Luna, S. M., Fauver, J. R., Rückert, C., Murrieta, R. A., Bergren, N., Samaras, D., Nguyen, C., Kading, R. C., \& Ebel, G. D. (2017). American Aedes vexans mosquitoes are competent vectors of Zika virus. The American Journal of Tropical Medicine and Hygiene, 96(6), 1338-1340. https://doi.org/10.4269/ ajtmh.16-0963

Grubaugh, N. D., Ladner, J. T., Kraemer, M. U. G., Dudas, G., Tan, A. L., Gangavarapu, K., Wiley, M. R., White, S., Thézé, J., Magnani, D. M., Prieto, K., Reyes, D., Bingham, A. M., Paul, L. M., Robles-Sikisaka, R., Oliveira, G., Pronty, D., Barcellona, C. M., Metsky, H. C., ... Andersen, K. G. (2017). Genomic epidemiology reveals multiple introductions of Zika virus into the United States. Nature, 546(7658), 401. https://doi. org/10.1038/nature22400

Hernández-Amparan, S., Pérez-Santiago, G., Correa-Ramírez, M. M., Reyes-Muñoz, J. L., Álvarez-Zagoya, R., \& Ibáñez-Bernal, S. (2017). First record of Aedes (Stegomyia) aegypti (L.) at Durango City, Mexico. Southwestern Entomologist, 42(3), 789-793.

Hijmans, R. J., Cameron, S. E., Parra, J. L., Jones, P. G., \& Jarvis, A. (2005). Very high resolution interpolated climate surfaces for global land areas. International Journal of Climatology, 25(15), 1965-1978. https:// doi.org/10.1002/joc.1276

Hijmans, R. J., \& van Etten, J. (2012). raster: Geographic analysis and modeling with raster data (Version 2.0-12) [Computer software]. Retrieved from http://CRAN.R-project.org/package=raster

Johansson, M. A., Mier-y-Teran-Romero, L., Reefhuis, J., Gilboa, S. M., \& Hills, S. L. (2016). Zika and the risk of microcephaly. New England Journal of Medicine, 375(1), 1-4. https://doi.org/10.1056/NEJMp 1605367

Johnson, L. R., Ben-Horin, T., Lafferty, K. D., McNally, A., Mordecai, E., Paaijmans, K. P., Pawar, S., \& Ryan, S. J. (2015). Understanding uncertainty in temperature effects on vector-borne disease: A Bayesian approach. Ecology, 96(1), 203-213. https://doi.org/10.1890/13-1964.1 
Jones, B., \& O'Neill, B. (2016). Spatially explicit global population scenarios consistent with the Shared Socioeconomic Pathways. Environmental Research Letters, 11(8), 084003. https://doi.org/10.1088/1748-9326/ $11 / 8 / 084003$

Jones, B., \& O'Neill, B. C. (2017). Global Population Projection Grids Based on Shared Socioeconomic Pathways (SSPs), 2010-2100. NASA Socioeconomic Data and Applications Center (SEDAC). Retrieved from https://doi.org/10.7927/H4RF5SOP

Kauffman, E. B., \& Kramer, L. D. (2017). Zika virus mosquito vectors: Competence, biology, and vector control. The Journal of Infectious Diseases, 216(suppl_10), S976-S990. https://doi.org/10.1093/infdis/ jix405

Kraemer, M. U., Brady, O. J., Watts, A., German, M., Hay, S. I., Khan, K., \& Bogoch, I. I. (2017). Zika virus transmission in Angola and the potential for further spread to other African settings. Transactions of the Royal Society of Tropical Medicine and Hygiene, 111(11), 527-529. https://doi.org/10.1093/trstmh/try001

Manore, C. A., Ostfeld, R. S., Agusto, F. B., Gaff, H., \& LaDeau, S. L. (2017). Defining the risk of Zika and chikungunya virus transmission in human population centers of the eastern United States. PLoS Neglected Tropical Diseases, 11(1), e0005255. https://doi. org/10.1371/journal.pntd.0005255

Moran, A. E., Oliver, J. T., Mirzaie, M., Forouzanfar, M. H., Chilov, M., Anderson, L., Morrison, J. L., Khan, A., Zhang, N., Haynes, N., Tran, J., Murphy, A., DeGennaro, V., Roth, G., Zhao, D., Peer, N., PichonRiviere, A., Rubinstein, A., Pogosova, N., ... Mensah, G. A. (2012). Assessing the global burden of ischemic heart disease: Part 1: Methods for a systematic review of the global epidemiology of ischemic heart disease in 1990 and 2010. Global Heart, 7(4), 315-329. https://doi.org/10.1016/j.gheart.2012.10.004

Mordecai, E. A., Cohen, J. M., Evans, M. V., Gudapati, P., Johnson, L. R., Lippi, C. A., Miazgowicz, K., Murdock, C. C., Rohr, J. R., Ryan, S. J., Savage, V., Shocket, M. S., Stewart Ibarra, A., Thomas, M. B., \& Weikel, D. P. (2017). Detecting the impact of temperature on transmission of Zika, dengue, and chikungunya using mechanistic models. PLoS Neglected Tropical Diseases, 11(4), e0005568. https://doi. org/10.1371/journal.pntd.0005568

Mordecai, E. A., Paaijmans, K. P., Johnson, L. R., Balzer, C., Ben-Horin, T., Moore, E., McNally, A., Pawar, S., Ryan, S. J., Smith, T. C., \& Lafferty, K. D. (2013). Optimal temperature for malaria transmission is dramatically lower than previously predicted. Ecology Letters, 16, 22-30. https://doi.org/10.1111/ele.12015

Muñoz, Á. G., Thomson, M. C., Stewart-lbarra, A. M., Vecchi, G. A., Chourio, X., Nájera, P., Moran, Z., \& Yang, X. (2017). Could the recent Zika epidemic have been predicted? Frontiers in Microbiology, 8, 1291. https://doi.org/10.3389/fmicb.2017.01291

Murdock, C. C., Paaijmans, K. P., Cox-Foster, D., Read, A. F., \& Thomas, M. B. (2012). Rethinking vector immunology: The role of environmental temperature in shaping resistance. Nature Reviews Microbiology, 10(12), 869-876. https://doi.org/10.1038/nrmicro2900

Musso, D., Rodriguez-Morales, A. J., Levi, J. E., Cao-Lormeau, V.-M., \& Gubler, D. J. (2018). Unexpected outbreaks of arbovirus infections: Lessons learned from the Pacific and tropical America. The Lancet Infectious Diseases, 18(11), e355-e361. https://doi.org/10.1016/ S1473-3099(18)30269-X

Netto, E. M., Moreira-Soto, A., Pedroso, C., Höser, C., Funk, S., Kucharski, A. J., Rockstroh, A., Kümmerer, B. M., Sampaio, G. S., Luz, E., Vaz, S. N., Dias, J. P., Bastos, F. A., Cabral, R., Kistemann, T., Ulbert, S., de Lamballerie, X., Jaenisch, T., Brady, O. J., ... Drexler, J. F. (2017). High Zika virus seroprevalence in Salvador, northeastern Brazil limits the potential for further outbreaks. MBio, 8(6), e01390-e01417. https:// doi.org/10.1128/mBio.01390-17

O'Reilly, K. M., Lowe, R., Edmunds, W. J., Mayaud, P., Kucharski, A., Eggo, R. M., Funk, S., Bhatia, D., Khan, K., Kraemer, M. U. G., Wilder-Smith, A., Rodrigues, L. C., Brasil, P., Massad, E., Jaenisch, T., Cauchemez, S.,
Brady, O. J., \& Yakob, L. (2018). Projecting the end of the Zika virus epidemic in Latin America: A modelling analysis. BMC Medicine, 16(1). https://doi.org/10.1186/s12916-018-1158-8

Riahi, K., van Vuuren, D. P., Kriegler, E., Edmonds, J., O'Neill, B. C., Fujimori, S., Bauer, N., Calvin, K., Dellink, R., Fricko, O., Lutz, W., Popp, A., Cuaresma, J. C., Kc, S., Leimbach, M., Jiang, L., Kram, T., Rao, S., Emmerling, J., ... Tavoni, M. (2017). The Shared Socioeconomic Pathways and their energy, land use, and greenhouse gas emissions implications: An overview. Global Environmental Change, 42, 153-168. https://doi.org/10.1016/j.gloenvcha.2016.05.009

Rodriguez-Barraquer, I., Costa, F., Nascimento, E. J. M., Nery, N., Castanha, P. M. S., Sacramento, G. A., Cruz, J., Carvalho, M., De Olivera, D., Hagan, J. E., Adhikarla, H., Wunder, E. A., Coêlho, D. F., Azar, S. R., Rossi, S. L., Vasilakis, N., Weaver, S. C., Ribeiro, G. S., Balmaseda, A., ... Ko, A. I. (2019). Impact of preexisting dengue immunity on Zika virus emergence in a dengue endemic region. Science, 363(6427), 607. https://doi.org/10.1126/science. aav6618

Ryan, S. J., Carlson, C. J., Mordecai, E. A., \& Johnson, L. R. (2019). Global expansion and redistribution of Aedes-borne virus transmission risk with climate change. PLoS Neglected Tropical Diseases, 13(3), e0007213. https://doi.org/10.1371/journal.pntd.0007213

Ryan, S. J., Lippi, C. A., \& Zermoglio, F. (2020). Shifting transmission risk for malaria in Africa with climate change: A framework for planning and intervention. Malaria Journal, 19(1), 1-14. https://doi. org/10.1186/s12936-020-03224-6

Ryan, S. J., McNally, A., Johnson, L. R., Mordecai, E. A., Ben-Horin, T., Paaijmans, K., \& Lafferty, K. D. (2015). Mapping physiological suitability limits for malaria in Africa under climate change. Vector-Borne and Zoonotic Diseases, 15(12), 717-725. https://doi.org/10.1089/ vbz.2015.1822

Sejvar, J. J. (2003). West nile virus: An historical overview. The Ochsner Journal, 5(3), 6-10.

Shocket, M. S., Ryan, S. J., \& Mordecai, E. A. (2018). Temperature explains broad patterns of Ross River virus transmission. elife, 7 , e37762. https://doi.org/10.7554/eLife.37762

Shragai, T., Tesla, B., Murdock, C., \& Harrington, L. C. (2017). Zika and chikungunya: Mosquito-borne viruses in a changing world. Annals of the New York Academy of Sciences, 1399(1), 61-77.

Siedner, M. J., Ryan, E. T., \& Bogoch, I. I. (2018). Gone or forgotten? The rise and fall of Zika virus. The Lancet Public Health, 3(3), e109-e110. https://doi.org/10.1016/S2468-2667(18)30029-X

Siraj, A. S., \& Perkins, T. A. (2017). Assessing the population at risk of Zika virus in Asia - Is the emergency really over? BMJ Global Health, 2(3), e000309. https://doi.org/10.1136/bmjgh-2017-000309

Tesla, B., Demakovsky, L. R., Mordecai, E. A., Ryan, S. J., Bonds, M. H., Ngonghala, C. N., Brindley, M. A., \& Murdock, C. C. (2018). Temperature drives Zika virus transmission: Evidence from empirical and mathematical models. Proceedings of the Royal Society of London B: Biological Sciences, 285, 20180795.

Waldorf, K. M. A., Olson, E. M., Nelson, B. R., Little, M.-T.-E., \& Rajagopal, L. (2018). The aftermath of Zika: Need for long-term monitoring of exposed children. Trends in Microbiology, 26(9), 729-732. https://doi. org/10.1016/j.tim.2018.05.011

Weaver, S. C. (2018). Prediction and prevention of urban arbovirus epidemics: A challenge for the global virology community. Antiviral Research, 156, 80-84. https://doi.org/10.1016/j.antiv iral.2018.06.009

Weger-Lucarelli, J., Rückert, C., Chotiwan, N., Nguyen, C., Garcia Luna, S. M., Fauver, J. R., Foy, B. D., Perera, R., Black, W. C., Kading, R. C., \& Ebel, G. D. (2016). Vector competence of American mosquitoes for three strains of Zika virus. PLoS Neglected Tropical Diseases, 10(10), e0005101. https://doi.org/10.1371/journal.pntd.0005101

Zambrana, J. V., Bustos Carrillo, F., Burger-Calderon, R., Collado, D., Sanchez, N., Ojeda, S., Carey Monterrey, J., Plazaola, M., Lopez, B., 
Arguello, S., Elizondo, D., Aviles, W., Coloma, J., Kuan, G., Balmaseda, A., Gordon, A., \& Harris, E. (2018). Seroprevalence, risk factor, and spatial analyses of Zika virus infection after the 2016 epidemic in Managua, Nicaragua. Proceedings of the National Academy of Sciences of the United States of America, 115(37), 9294-9299. https://doi. org/10.1073/pnas.1804672115

Zhu, Z., Chan, J.-F.-W., Tee, K.-M., Choi, G.-K.-Y., Lau, S.-K.-P., Woo, P.-C.-Y., Tse, H., \& Yuen, K.-Y. (2016). Comparative genomic analysis of pre-epidemic and epidemic Zika virus strains for virological factors potentially associated with the rapidly expanding epidemic. Emerging Microbes \& Infections, 5(3), e22. https://doi.org/10.1038/emi. 2016.48

\section{SUPPORTING INFORMATION}

Additional supporting information may be found online in the Supporting Information section.

How to cite this article: Ryan SJ, Carlson CJ, Tesla B, et al. Warming temperatures could expose more than 1.3 billion new people to Zika virus risk by 2050. Glob Change Biol. 2020;00:1-10. https://doi.org/10.1111/gcb.15384 